\title{
REGIONAL DISPARITIES IN HUNGARIAN URBAN ENERGY CONSUMPTION - A LINK BETWEEN SMART CITIES AND SUCCESSFUL CITIES
}

\author{
Zoltán NAGY1 , Tekla SEBESTYÉN SZÉP' , Dóra SZENDI ${ }^{1}$
}

DOI: 10.21163/GT_2019. 141.07

\begin{abstract}
:
Cities account for $60-80 \%$ of global energy consumption, and based on projections the development of urban areas will be the main engine of energy use growth in the future. While it may seem that this topic plays only a marginal role in urban research, in energy economics more and more studies are focusing on the concept of the smart energy city and resilient city related to energy use as a possible way toward sustainability and human wellbeing. Our main objective is to examine the dimension of smart environment through residential energy use. We focus on the regional disparities of urban energy use (electricity use and natural gas consumption) in Hungary. The analysis covers 23 Hungarian cities and Budapest during the period from 2010 to 2015. The Theil Index and the area-based Gini index are calculated. We conclude that on the whole no significant inequalities or spatial differences were identified among the cities. The Theil Index components (within-group inequality component and between-group inequality component) draw attention to the within-group differences related to natural gas consumption. These disparities are more decisive than values of the between-group inequality components. It cannot be stated that belonging to the "elite" groups of cities causes significant changes in the urban electricity and natural gas consumption patterns.
\end{abstract}

Key-words: AR-Gini, Theil index, Residential energy use, Disparities.

\section{INTRODUCTION}

Globally circa 210 million people without access to electricity live in urban areas and furthermore, approximately 500 million people still lack access to clean cooking facilities World Bank (2018). As Szlávik (2013) emphasizes, we cannot wait for an enlightened world government; a sustainable social, economic and political system can be achieved only at the local level with sustainable projects. Local initiatives and corporate social responsibility are highly important. There are no breakthroughs leading to sustainability (which is so popular nowadays), only small movements and shifts. There are economic decisions and objectives that can be achieved under the current circumstances, make a profit, improve well-being and serve the aims of sustainability as well. Actually, sustainable development can be interpreted as the long-term strategy of humanity. It exists not only globally but also on regional and local levels. With an increasing share of renewable energy sources and with local solutions to global problems, the role of decentralization, local approach to energy policy and local economic and community development are being revaluated. The smart city concept can be the basis for these comprehensive social, economic and technological changes. This definition does not refer to a completed

\footnotetext{
${ }^{1}$ Institute of World and Regional Economics, Faculty of Economics, University of Miskolc 3515

Miskolc-Egyetemváros, Hungary,nagy.zoltan@uni-miskolc.hu,regtekla@uni-miskolc.hu, regszdor@uni-miskolc.hu
} 
state/status, but to an operation logic and continuous development (Kulcsár and Szemerey 2016; Sáfián and Munkácsy 2015).

\section{THEORETICAL BACKGROUND}

The smart city concept is not novel in the economic literature. It first emerged in the 1990s (although the intensity of related research increased significantly after 2009, according to Jong et al. 2015) with regard to the sustainable development of urban areas and settlements and the reforms of the urban management systems (Kulcsár and Szemerey 2016). Hollands (2008) mentions San Diego, San Francisco, Amsterdam and Kyoto, as the first users of smart applications and technologies. However, Manchester, Southampton and Vancouver are presented for their best practices and good initiatives. As Egedy (2017) concludes, the three main pillars (or dimensions) of the smart city concept are sustainability, efficiency and wide participation. There are many other kinds of categories and definitions related to the smart city concept: eco city, sustainable city, low carbon city, knowledge city, intelligent city, digital city, resilient city, ubiquitous city, green city, information city, liveable city, hybrid city, creative city, humane city, learning city, wired city.

The borders often blur and there are significant overlaps; a detailed overview is given by Jong et al. (2015). The definition of smart city can be interpreted from two perspectives: there is a technical interpretation, which emphasizes the physical implementation of smart innovations and see the future in urban planning and decision-making based on algorithms (Baji 2017). From a social viewpoint, the main goal of these innovative solutions and improvements is a more democratic society and the active participation of citizens in community decisions that contribute to sustainable development and a higher quality of life (Jong et al. 2015).

The environmental dimension supplements this and it focuses on the "smart and green" technologies (Baji 2017). It targets the ecological improvement of urban areas. Important fields are urban water management, lighting, waste management, management of natural resources and energy management (these are relevant fields of environmental sustainability as well). It is worth examining how the performance of a selected city (related to these indicators) is compared to other urban areas. Are there social or spatial reasons for the differences? Can these differences be explained by the attitudes of the residents? We can get a clear picture about the environmental consciousness of residents then the intervention points become identifiable (Baji 2017). A well-functioning smart city may contribute to improving living standards, increasing urban competitiveness and overcoming obstacles such as poverty, social exclusion or environmental problems.

Our current study focuses on the environmental dimension of smart cities as a critical field of the smart city concept. Investigating the smart solutions that are running and under implementation, it can be stated that application of environmental solutions plays a significant role.

From our perspective efficient energy use is the most important. Most of the concepts emphasize it, such as Nam and Pardo (2011), Lados (2011), Cohen (2014), Stankovic et al. (2017) and the ISO 37120 standard as well. Energy efficiency improvements can bear many positive external effects, such as direct effects (increasing the value of real estate, enhancing quality of life, intensifying tourism, development of the local smart business environment). Based on Giffinger (2015) the development of a smart environment can also 
lead (directly or indirectly) to negative impacts, and this phenomenon is called the rebound effect. This suggests that the energy use of smart cities should be examined in more depth.

In this study a situation report is carried out that provides an energy efficiency overview for Hungarian cities (with county rights) to map the starting solution. We provide a review of the "elite category" of Hungarian medium-sized cities (based on Rechnitzer et al. 2014). In our view the most realistic chance of introducing smart apps and creating a smart city concept can be in this category (in some of these cities these initiatives have already started).

The research questions are: 1) Could be significant differences detected in the residential energy use of the selected cities (regarding the subcategory of "elite" cities)? 2) How these differences changed between 2010 and 2015 ?

\section{DATA AND METHODOLOGY}

In this study the regional disparities and the spatial distribution of Hungarian urban energy use (electricity use and natural gas consumption) are examined. The analysis covers 23 Hungarian towns with county rights and Budapest during the period of 2010-2015. The 23 towns are the following: Békéscsaba, Debrecen, Dunaújváros, Eger, Érd, Győr, Hódmezővásárhely, Kaposvár, Kecskemét, Miskolc, Nagykanizsa, Nyíregyháza, Pécs, Salgótarján, Sopron, Szeged, Székesfehérvár, Szekszárd, Szolnok, Szombathely, Tatabánya, Veszprém, Zalaegerszeg.

Annual data as listed below are applied in the calculations collected from the Hungarian Central Statistical Office (KSH): gross income (local currency unit LCU); resident population at the end of the year (data calculated further from finalised data of the population census); number of household electricity consumers; volume of electricity supplied to households (thousand $\mathrm{kWh}$ ); total volume of electricity supplied (thousand $\mathrm{kWh}$ ); total volume of piped gas supplied (not recalculated) (thousand $\mathrm{m}^{3}$ ); of total volume of gas supplied, volume of gas supplied to households (not recalculated) (thousand $\mathrm{m}^{3}$ ); of household gas consumers, number of those using gas for heating.

Based on these data we created the following indicators: residential gas consumption per household $\left(\mathrm{m}^{3}\right)$, residential electricity consumption per household $(\mathrm{kWh})$, natural gas consumption per capita $\left(\mathrm{m}^{3}\right)$, electricity consumption per capita $(\mathrm{kWh})$, income per capita (HUF). Application of these indicators enable us to compare the selected cities with different economic structure.

\subsection{Theil index}

Conceição and Ferreira (2000) argue that inequality can be measured not only in the case of individuals (total inequality), but in the case of groups (between-group inequality) as well. Grouping individuals can be calculated on an area basis, or sex, qualifications, rural or urban population or even income deciles can serve as grouping criteria. If the groups are formed on a geographical basis, we intend to investigate and analyse the spatial difference of a selected indicator. The Theil index has become a very frequently used tool for regional differences (it used in e.g. Alcantara and Duro 2004, Zhang L. 2011).

The Theil index - similar to decomposition methods - consists of two components, i.e., a within-group inequality component and a between-group inequality component. Actually, the selected component shows - assuming the constancy/unchangingness of other indicators - the impact of the specific factor on the dependent variable. Based on Zhang et al. (2011) the formula of the Theil index is: 


$$
T(I)=\sum_{i} y_{i} \ln \left(\frac{\bar{I}}{I_{i}}\right)
$$

where $y_{i}$ is the gross income-share for city $i$ for a given year; $\bar{I}$ is average value of the measured (specific) energy data (considering the examined towns); $I_{i}$ denotes the concerned indicator for city $i$. Similar to Zhang et al. (2011), in this study specific data (not total or absolute, but per capita or per household) are involved.

$$
T(I)=T_{B}(I)+T_{W}(I)
$$

where $T_{B}(I)$ is the aggregate between-group variance component; $T_{W}(I)$ is the aggregate within-group component.

$$
T_{B}(I)=\sum_{g} y_{g} * \ln \left(\frac{\bar{I}}{\bar{I}_{g}}\right)
$$

where $y_{g}$ is the gross income share of group $g ; \overline{I_{g}}$ is the average of the cities in group $g$ (related to the selected specific energy data).

$$
T_{W}(I)=\sum_{g} \sum_{i} y_{g} * y_{i . g} * \ln \left(\frac{\bar{I}_{g}}{I_{i, g}}\right)
$$

where $y_{i, g}$ is the gross income share associated with city $i$ in group $g ; I_{i, g}$ denotes the concerned indicator for city $i$ in group $g$.

In the index zero indicates no inequality, while higher values of the index indicate greater disparity (the maximum value of the index is 1 , indicating complete inequality).

Classification of the Hungarian towns with county rights has a significant literature (such as Lengyel 1999, Beluszky and Győri 2004). Here we cite Rechnitzer et al. (2014). The researchers, investigating the innovation clusters, conclude that in Hungary 17 towns (from the group of 23 Hungarian towns with county rights) can be grouped into an "elite" category (these are Pécs, Sopron, Miskolc, Szeged, Szolnok, Szekszárd, Kaposvár, Kecskemét, Szombathely, Debrecen, Eger, Zalaegerszeg, Veszprém, Nyíregyháza, Győr, Dunaújváros and Székesfehérvár), while 6 towns are not part of the group (Békéscsaba, Érd, Hódmezővásárhely, Nagykanizsa, Salgótarján and Tatabánya). The so-called "elite" category contains towns with outstanding features from the point of view of innovation and human development. These settlements have complex economic structures and are regional centres with great economic potential or with an economy that is highly oriented towards research, development and higher education (Rechnitzer et al. 2014). Calculation of the components for the Theil index is based on this classification.

\subsection{AR-Gini index}

The Gini coefficient is derived from the Lorenz curve. The Lorenz curve is especially suitable for the graphical representation of social inequalities, and has become a popular tool to illustrate not only income and the expenditure-related inequalities, but spatial variations as well (such as Dollman et al. 2015, Finn et al. 2009, Steinberger et al. 2010). The latter 'shows the share of spending (or income) by households ranked by spending (or income). The further the curve is below the 45 degree line, the less equal the distribution. Correspondingly, the Gini coefficient is calculated as the area between the Lorenz curve 
and the 45 degree line divided by the total area under the 45 degree line.' (Dollman et al. 2015) The higher the coefficient, the more unequal the distribution is.

Application of the area-based Gini-index (called the AR-Gini index) can contribute to revealing the main reasons of the spatial inequalities. It is used in many research fields and is a frequently used tool for the examination of energy sources, energy use, different types of environmental damage (such as acidity, depletion of the ozone layer, emission, eutrophication, climate change), and for life-cycle- based (from cradle to grave) analysis of material flows (such as Steinberger et al. 2010).

The AR-Gini differs from the conventional Gini coefficient in two points (Table 1). First, the measure of disparity in terms of resource use is carried out using any physical unit (it is not monetarily expressed), second it is calculated on an area basis (not at the level of households or individuals) (Druckman and Jackson 2008).

Table 1

Comparison of AR-Gini and the original Gini index

\begin{tabular}{|l|l|l|}
\hline \multicolumn{1}{|c|}{ AR-Gini } & \multicolumn{1}{c|}{ Gini } \\
\hline calculation basis & calculated on an area basis & $\begin{array}{l}\text { calculated on a per capita or } \\
\text { household basis }\end{array}$ \\
\hline object of calculation & calculated on a resource basis & $\begin{array}{l}\text { income, wealth, expenditures } \\
\text { (calculated on a monetary basis) }\end{array}$ \\
\hline
\end{tabular}

Source: own compilation based on Druckman and Jackson (2008)

Calculation of the Gini coefficient for income is carried out using the following equation (Druckman and Jackson 2008):

$$
G=\frac{1}{2 n^{2} \eta} \sum_{i=1}^{n} \sum_{j=1}^{n}\left|y^{i}-y^{j}\right|
$$

where $y^{i}$ and $y^{j}$ are the incomes of the $i$ th and $j$ th household, $\eta$ is the average income and $n$ is the number of households. Adapting this formula to the calculation of AR-Gini, the explanation of the equation changes as well: $y^{i}$ and $y^{j}$ denote the average resource use in $i$ th and $j$ th area (in this study the resource use means the electricity consumption or natural gas use), $\eta$ is the average resource use of each area, $n$ is the number of output selected areas.

\section{RESULTS}

As discussed above, no significant differences between the rural and urban (23 Hungarian towns with county rights and Budapest) energy use are found. According to the KSH (2018) database, while in $201537.5 \%$ of the Hungarian population lived in one of the 23 cities with county rights or in Budapest, $37.3 \%$ of the volume of electricity supplied to households and $40.4 \%$ of the volume of gas supplied to households were concentrated here. However, the question arises as to what differences can be observed among the energy use of the examined cities and whether there is any connection between their success (meaning belonging to the elite category based on Rechnitzer et al. 2014) and their energy consumption patterns. Or from the other side, whether the achieved level of energy efficiency and the decreasing energy use can contribute to urban development or to success. Does the society of the more developed or more successful cities consume (natural) resources more efficiently and more consciously? 
To visualize the differences among the selected cities (regarding the selected variables) the Standard Deviation Method is applied and the distribution of data was displayed with a box plot chart (Fig. 1). Here the outliers are filtered out and the results slightly differ from the Gini coefficient values (Table 2). The latter highlights that the social disparities are the lowest among the selected cities in case of income per capita. The inequalities significantly decreased in the case of natural gas consumption (per household and per capita). The social differences regarding residential electricity consumption per household have hardly changed between 2010 and 2015. However, in the case of electricity consumption per capita a slight increase in Gini coefficient can be observed: the value of it is 0.24 in 2010 and 0.28 in 2015 (but this does not refer to an extremely high inequality).

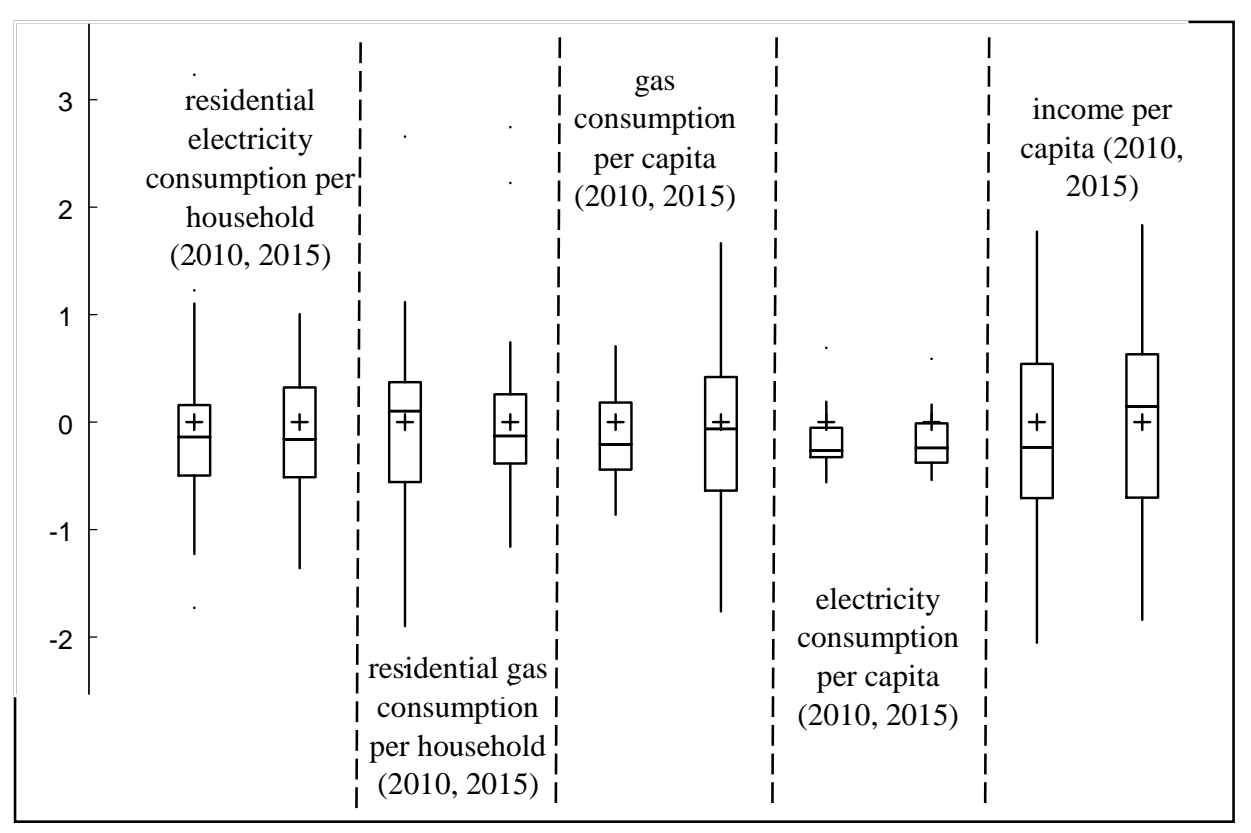

Fig. 1. Box plot of selected variables

Source: own compilation based on KSH (2019).

These trends are almost certainly related to the fact that between 2010 and 2012 a significant part of the society (the $1^{\text {st }}-3^{\text {rd }}-4^{\text {th }}-5^{\text {th }}-6^{\text {th }}-8^{\text {th }}-9^{\text {th }}$ income deciles) decreased their energy expenditures. These households restrained their consumption and many switched energy sources, at least partly, from natural gas to cheaper sources (typically the expenditures on solid fuels, especially on wood, increased). In subsequent years the positive effects of energy efficiency improvements financially supported by the European Union funds could be realized. As a result of the utility cost reduction program (2013-2014), with special regard to the price effect, the social disparities related to the energy expenditure per household declined. However, residential energy consumption increased (this complex process is presented in detail in Sebestyénné Szép 2018). 
Table 2

Gini coefficient values for the electricity consumption, natural gas use and the income per capita, in case of Budapest and Hungarian cities with county rights $(2010,2015)$

\begin{tabular}{|l|c|c|c|c|r|}
\hline & $\begin{array}{c}\text { Natural gas } \\
\text { consumption } \\
\text { per capita } \\
(\mathbf{m 3})\end{array}$ & $\begin{array}{c}\text { Residential gas } \\
\text { consumption } \\
\text { per household } \\
(\mathbf{m 3})\end{array}$ & $\begin{array}{c}\text { Electricity } \\
\text { consumption } \\
\text { per capita } \\
\mathbf{( k W h )}\end{array}$ & $\begin{array}{c}\text { Residential } \\
\text { electricity } \\
\text { consumption } \\
\text { per household } \\
\text { (kWh) }\end{array}$ & $\begin{array}{c}\text { Income } \\
\text { per } \\
\text { capita } \\
\text { (HUF) }\end{array}$ \\
\hline Gini index (2010) & 0.22 & 0.16 & 0.24 & 0.1 & 0.07 \\
\hline Gini index (2015) & 0.15 & 0.13 & 0.28 & 0.1 & 0.07 \\
\hline
\end{tabular}

Source: own calculation.

The results of the AR-Gini index (Table 2) and the Theil index (Table 3) show similarities regarding electricity consumption. While spatial differences cannot be observed related to the residential electricity consumption per household, the results of the Theil index associated with electricity consumption per capita data indicate a small, but increasing tendency over time, where the within-group inequality component plays a greater role than the between-group inequality component.

The Theil indices associated with natural gas consumption (Table 3) confirm the results of the AR-Gini coefficient; a small and downward tendency can be identified in both categories (residential gas consumption per household $\left(\mathrm{m}^{3}\right)$ and natural gas consumption per capita $\left(\mathrm{m}^{3}\right)$ ). The Theil index components (within-group inequality component and between-group inequality component) call attention to the differences in the within-group inequality component. These disparities are more important than the values of the betweengroup inequality components. It cannot be stated that the success, i.e. belonging to the "elite" category, causes significant changes in urban electricity and natural gas consumption patterns.

Table 3

Theil index with regard to electricity and natural gas consumption for the Hungarian towns with county rights and Budapest $(\mathbf{2 0 1 0 , 2 0 1 5 ) .}$

\begin{tabular}{|c|c|c|c|c|}
\hline Indicator & Year & $\begin{array}{l}\text { Theil } \\
\text { index }\end{array}$ & $\begin{array}{c}\text { Between-group } \\
\text { inequality } \\
\text { component }\left(\mathbf{T}_{\mathbf{B}}(\mathrm{I})\right)\end{array}$ & $\begin{array}{l}\text { Within-group } \\
\text { inequality } \\
\text { component } \\
\left(T_{w}(I)\right) \\
\end{array}$ \\
\hline \multirow{2}{*}{$\begin{array}{l}\text { natural gas consumption per } \\
\text { capita }\left(\mathrm{m}^{3}\right)\end{array}$} & 2010 & 0.097 & -0.001 & 0.098 \\
\hline & 2015 & 0.018 & -0.018 & 0.036 \\
\hline \multirow{2}{*}{$\begin{array}{c}\text { residential gas consumption per } \\
\text { household }\left(\mathrm{m}^{3}\right)\end{array}$} & 2010 & 0.104 & 0.037 & 0.068 \\
\hline & 2015 & 0.047 & 0.040 & 0.007 \\
\hline \multirow{2}{*}{$\begin{array}{c}\text { electricity consumption per capita } \\
(\mathrm{kWh})\end{array}$} & 2010 & 0.111 & -0.024 & 0.135 \\
\hline & 2015 & 0.125 & -0.030 & 0.155 \\
\hline \multirow{2}{*}{$\begin{array}{c}\text { residential electricity consumption } \\
\text { per household }(k W h)\end{array}$} & 2010 & 0.00 & 0.02 & -0.02 \\
\hline & 2015 & 0.00 & 0.01 & -0.01 \\
\hline
\end{tabular}

Source: own calculations

The results can be explained by the rebound effect and by high human development index (HDI) values. According to Sorrell et al. (2009) 'the rebound effect is an umbrella term for a variety of mechanisms that reduce the potential energy savings from improved energy efficiency' (Sorrell et al. 2009, p. 1457). The rebound effect shows as a result of 
energy efficiency improvements, how much the additional residential energy use is, and what percentage of potential energy savings are lost. Madlener and Alcott (2009) conclude that the size of the rebound effect in the long run is between $10 \%$ and $30 \%$. A previous study of ours (Sebestyénné Szép 2013) identifies a lower result: the rebound effect associated with the residential energy consumption was $15 \%$ in East-Central Europe between 1990 and 2009. This finding is crucially important from the point of this study; this fact can explain why no significant difference can be detected among the residential energy use patterns in the selected cities. Probably in the richer, more successful cities (with higher income per capita) the residents can afford to buy modern (more energy efficient) household devices. They heat with better boilers (and probably they use gas for heating), but in the poorer and less successful towns many of the households switched the energy source for heating from electricity and natural gas to wood (in the context of rising energy prices). So the residents living in cities with higher gross income use more appliances and other energy-consuming devices, but their equipment is newer and more efficient, so its energy use is lower as well. By contrast the urban population in the poorer cities (with lower gross income per capita) is less able to afford to replace household appliances. The two processes actually balance each other: the richer use more, but in more efficient way, the poorer uses less, but with higher energy intensity.

Many studies focus on the relation between the degree of development of a country and its energy consumption development (this former is usually measured with HDI) (e.g. Arto et al. 2016; Steinberger and Roberts 2010; Martínez and Ebenhack 2008; Dias et al. 2006; Pasternak 2001). These papers emphasize that the energy use patterns of countries with HDI of 0.7-0.9 are similar, while significant growth in the energy use level is achieved in countries with HDI over 0.9. Pasternak (2001) concludes that there no country with annual electricity consumption below $4000 \mathrm{kWh}$ per capita that has an HDI of 0.9 or higher (the examined time period in this case was 1980-1997). Above $5000 \mathrm{kWh}$ per capita, no country has an HDI under 0.9 (cited in Arto et al. 2016). These publications describe this relation at national level, but analysis of the lower spatial levels (especially the urban analysis) is quite rare. This can be explained by limited data and methodological problems. Probably - if we start from the context described above - a similar process can be experienced at the urban level as well. So above a certain level of HDI - naturally it is achieved in all examined cities - increase in per capita energy consumption is no longer expected (the Hungarian HDI was 0.836 in 2015 according to UNDP (2018)). So development, or success, is separate from the additional energy use - and partly related to the Kuznets curve - the dematerialization is achieved. This is confirmed by Csák (2015). He concludes that the consumer culture is homogeneous - including also the opportunities as well - so the consumption of an area is determined by the intensity of its economic activities.

\section{CONCLUSION}

In this study we examined the regional disparities of urban energy use (electricity use and natural gas consumption) in Hungary. The analysis covered 23 Hungarian towns with county rights and Budapest during the period of 2010-2015. The Theil Index and the area based Gini-index were calculated as well. The basic research question is related to the size of inequalities based on the environmental components of smart cities. The following findings were made:

1. Significant differences between the rural and urban (23 Hungarian towns with county rights and Budapest) energy use were not experienced. 
2. In the case of the examined cities significant inequalities and large spatial variances were not revealed with regard to the indicators of urban energy consumption (i.e. residential electricity consumption per household, residential gas consumption per household, natural gas consumption per capita, electricity consumption per capita). Furthermore, the already small territorial differences typically decreased between 2010 and 2015.

3. The Theil index components (within-group inequality component and betweengroup inequality component) call attention to the differences in within-group inequality component related to natural gas consumption (natural gas consumption per capita, and residential gas consumption per household) and electricity use per capita. It is evident that within-group disparities are currently the most important factor explaining the level variance in these energy indicators across the 24 cities involved in the study. These disparities are more important than values of the between-group inequality components.

4. It was not found that the success (i.e. belonging to the "elite" category) causes significant changes in urban electricity and natural gas consumption patterns.

5. There is a strong positive correlation between the electricity use per capita $(\mathrm{kWh})$ and the income per capita, and between the natural gas consumption per capita $\left(\mathrm{m}^{3}\right)$ and the income per capita.

In summary, focusing on the dimension of smart environment it can be concluded that significant spatial inequalities do not arise among the Hungarian cities with county rights in relation to the examined indicators of electricity use and natural gas consumption.

\section{ACKNOWLEDGEMENT}

This research was supported by the project no. EFOP-3.6.2-16-2017-00007, titled Aspects on the development of intelligent, sustainable and inclusive society: social, technological, innovation networks in employment and digital economy. The project has been supported by the European Union, co-financed by the European Social Fund and the budget of Hungary. A part of this study was previously published in Hungarian (Nagy, Z., Sebestyénné Szép, T., Szendi D. (2018): Területi különbségek a magyar megyei jogú városok energiafelhasználásában - I-II. rész. Területi Statisztika, 58(5): 447-461; 58(6): 551-566).

\section{R E F E R E N C ES}

Alcantara V., Duro J. A. (2004): Inequality of energy intensities across OECD countries: a note. Energy Policy, 32 (11), pp. 1257-1260

Arto, I., Capellán-Pérez, I., Lago, R., Bueno, G., Bermejo, R. (2016): The energy requirement of a developed world. Energy for Sustainable Development, 33, pp.1-13.

Baji P. (2017): Okos városok és alrendszereik - Kihívások a jövő városkutatói számára? (S mart cities and their domains - Future challenges for urban researchers?). Tér és Társadalom, 31 (1), pp.89105.

Beluszky P., Győri R. (2004): Fel is út, le is út... Városaink településhierarchiában elfoglalt pozícióinak változásai a 20. században. (Rise and fall... Changes in hierarchical position of the Hungarian cities in the XX. century). Tér és Társadalom, Vol. 1. pp. 1-41. 
Cohen, B. (2014): Estudio "Ranking de Ciudades Inteligentes en Chile"; Fundacion pais digital, Universidad del Desarrollo. http://dg6223fhel5c2.cloudfront.net/PD/wpcontent/uploads/2014/06/Ranking-Ciudades-Inteligentes-en-Chile.pdf

Conceição P., Ferreira P. (2000): The Young Person's Guide to the Theil Index: Suggesting Intuitive Interpretations and Exploring Analytical Applications. UTIP Working Paper Number 14. https://utip.lbj.utexas.edu/papers/utip_14.pdf

Csák L. (2015): Energiapolitika: minden területi szinten. (Energy policy: on all territorial levels). Tér és Társadalom, 29.évf., 4.szám

Dias R. A., Mattos C., R., Balestieri J. A. P. (2006): The limits of human development and the use of energy and natural resources. Energy Policy, Volume 34, Issue 9, pp.1026-1031.

Dollman R., Kaplan G., La Cava G., Stone T. (2015): Household economic inequality in Australia. Research Discussion Paper 2015-15, Reserve Bank of Australia, Sydney. https://gregkaplan.uchicago.edu/sites/gregkaplan.uchicago.edu/files/uploads/dollman_kaplan_laca va_stone.pdf

Druckman A., Jackson T. (2008): Measuring resource inequalities: The concepts and methodology for an area-based Gini coefficient. Ecological Economics, Volume 65, Issue 2, pp. 242-252

Egedy T. (2017): Városfejlesztési paradigmák az új évezredben - a kreatív város és az okos város. (Urban development paradigms in the new millennium - the creative city and the smart city). Földrajzi Közlemények, 141.3. pp.254-262.

Finn A., Leibbrandt M., Woolard I. (2009): Income \& expenditure inequality: analysis of the NIDS Wavw 1 dataset. Discussion Paper 5. National Income Dynamics Study. http://www.nids.uct.ac.za/publications/discussion-papers/wave-1-papers/96-nids-discussionpaper-no05/file

Giffinger, R. (2015): Smart City concepts: chances and risks of energy efficient urban development. Smartgreens Conference, IV. International Conference on Smart Cities and green ICT systems. Lisbon. http://www.smartgreens.org/Documents/Previous_Invited_Speakers/2015/SMARTGREENS2015 _Giffinger.pdf

Hollands G. R. (2008): Will the real smart city please stand up? City, 12(3), pp. 303-320.

Jong M., Joss S., Schraven D., Zhan C., Weijnen M. (2015):_Sustainable-smart-resilient-low carboneco-knowledge cities; making sense of a multitude of concepts promoting sustainable urbanization. Journal of Cleaner Production, Volume 109, pp. 25-38

KSH (2018): Dissemination Database. Hungarian Central Statistical Office. http://statinfo.ksh.hu/Statinfo/themeSelector.jsp?\&lang=hu

Kulcsár S., Szemerey S. (2016): Okos városok, intelligens városfejlesztés: Az intelligens városfejlesztés keretei. (Smart cities, intelligent urban development: Frames of the intelligent urban development) Falu Város Régió, 2, pp. 26-33

Lados M. (editor) (2011): „Smart Cities” tanulmány. (Smarti cities paper). IBM, MTA Regionális Kutatások Központja, Nyugat-magyarországi Tudományos Intézet, Győr. http://www.rkk.hu/rkk/news/2011/smart_cities_tanulmany_IBM_RKK.pdf

Lengyel I. (1999): Mérni a mérhetetlent? A megyei jogú városok vizsgálata többdimenziós skálázással. (Measuring of immeasurable? Analysis of towns of county rank with multidimensional scaling). Tér és Társadalom Vol.1-2. pp. 53-73.

Madlener R., Alcott B. (2009): Energy rebound and economic growth; A review of the main issues and research needs. Energy 34. pp.370-376.

Martínez D. M., Ebenhack B. W. (2008): Understanding the role of energy consumption in human development through the use of saturation phenomena. Energy Policy, Volume 36, Issue 4, pp.1430-1435

Nam, T., Pardo, T. A. (2011): Conceptualizing Smart City With Dimensions of Technology, People, and Institutions, from Proceedings of the 12th Annual International Digital Government Research Conference: Digital Government Innovation in Challenging Times, ACM New York, NY. 
Pasternak, A.D. (2001). Global energy futures and human development: a framework for analysis. Global 2001 international conference on: "back-end of the fuel cycle: from research to solutions", France.

Rechnitzer J., Páthy Á., Berkes J. (2014): A magyar városhálózat stabilitása és változása. (Stability and change in the Hungarian city network). Tér és társadalom, 28. pp.105-127.

Sáfián F., Munkácsy B. (2015): A decentralizált energiarendszer és a közösségi energiatermelés lehetőségei a településfejlesztésben magyarországon. (The opportunities of decentralized energy systems and community energy production in settlement development in Hungary). Földrajzi Közlemények 2015. 139. 4. pp.257-272.

Sebestyénné Szép T. (2013): Energiahatékonyság: áldás vagy átok? (Energy efficiency: malediction and benediction?) Területi statisztika, Központi Statisztikai Hivatal, 53 (1), pp.54-68.

Sebestyénné Szép T. (2018): A hatósági árcsökkentés lakossági energiafelhasználásra gyakorolt hatásának vizsgálata indexdekompozícióval. (Analysing the effects of utility-cost reduction on household energy consumption, using index decomposition) Közgazdasági Szemle. Vol. LXV., pp. 185-205, DOI:10.18414/KSZ.2018.2.185

Sorrell S. (2009): Jevons' Paradox revisited: The evidence for backfire from improved energy efficiency. Energy Policy 37. pp.1456-1469 https://doi.org/10.1016/j.enpol.2008.12.003

Stankovic, J., Dzunic, M., Dzunic, Z, Marinkovic, S. (2017). A multi-criteria evaluation of the European cities' smart performance: Economic, social and environmental aspects; Zb. rad. Ekon. fak. Rij. 35(2), pp. 519-550.

Steinberger J. K., Roberts, J. T. (2010): From constraint to sufficiency: the decoupling of energy and carbon from human needs, 1975-2005. Ecological Economics, volume 70, issue 2, pp.425-433

Szlávik J. (2013): Fenntartható gazdálkodás. (Sustainable economy) CompLex Kiadó, Budapest

UNDP (2018): Human Development Indices and Indicators: 2018 Statistical Update. United Nations Development Programme. http://hdr.undp.org/sites/all/themes/hdr_theme/country-notes/HUN.pdf

World Bank (2018): SE4ALL Database http://databank.worldbank.org/data/reports.aspx?source=sustainable-energy-for-all

Zhang L., Yang Z., Liang J., Cai Y. (2011): Spatial Variation and distribution of Urban Energy Consumptions from Cities in China. Energies, 4, pp.26-38. 